\title{
Flow-based regenerable chemiluminescence receptor assay for the detection of tetracyclines
}

\author{
Verena K. Meyer ${ }^{1} \cdot$ Claire V. Chatelle $^{2} \cdot$ Wilfried Weber $^{2} \cdot$ Reinhard Niessner $^{1} \cdot$ Michael Seidel $^{1}$ \\ Received: 10 October 2019 / Revised: 6 December 2019 / Accepted: 19 December 2019 / Published online: 16 January 2020 \\ (C) The Author(s) 2020
}

\begin{abstract}
For the first time, a flow-based regenerable chemiluminescence receptor assay is established that is eminently suited as screening method for the detection of widely used tetracyclines (TCs) in environmental and food samples. The complex functionality and high reactivity of TCs complicate the creation of immunogens which is currently the bottleneck for developing sensitive immunoassays. In this case, competitive bioreceptor assays for the analysis of small organic molecules are preferable and, moreover, flow-based regenerable bioassays are optimally suited for automated analysis applications. Therefore, the solution for rapid and sensitive analysis of TCs is the regenerable CL receptor assay with a covalently immobilized DNA oligonucleotide containing the specific operator sequence tetO to which the repressor protein TetR binds only in the absence of TCs. The TC measurements are performed on the CL microarray analysis platform MCR 3 within 30 min per sample. The LoD in spiked tap water was determined to be $0.1 \mu \mathrm{g} \mathrm{L}^{-1}$, and for $1 \mu \mathrm{g} \mathrm{L} \mathrm{L}^{-1} \mathrm{TET}$, recoveries of $77 \% \pm 16 \%$ were obtained. Due to the stability of the immobilized DNA oligonucleotide and the resulting regenerability of the assay for various measurements, the new method is highly cost- and resource-efficient and ideally suited for the monitoring of environmental samples in the field.
\end{abstract}

Keywords Receptor assay $\cdot$ Antibiotics $\cdot$ Tetracyclines $\cdot$ Chemiluminescence microarray $\cdot$ Regenerable biosensor

\begin{tabular}{|c|c|c|}
\hline \multicolumn{3}{|c|}{ Abbreviations } \\
\hline \multicolumn{2}{|c|}{ CCD } & Charge-coupled device \\
\hline \multicolumn{2}{|c|}{ CL } & Chemiluminescence \\
\hline \multicolumn{2}{|c|}{ CTC } & Chlortetracycline \\
\hline \multicolumn{2}{|c|}{ DNA } & Deoxyribonucleic acid \\
\hline \multicolumn{2}{|c|}{ DOX } & Doxycycline \\
\hline \multicolumn{2}{|c|}{ ELISA } & Enzyme-linked immunosorbent assay \\
\hline \multicolumn{2}{|c|}{$\mathrm{His}_{6} / \mathrm{His}_{5}$} & Hexa/pentahistidine \\
\hline \multicolumn{2}{|c|}{ HPLC-MS } & $\begin{array}{l}\text { High-performance liquid } \\
\text { chromatography-mass spectrometry }\end{array}$ \\
\hline \multicolumn{2}{|c|}{ HRP } & Horseradish peroxidase \\
\hline \multicolumn{3}{|c|}{$\begin{array}{l}\text { Published in the topical collection Advances in Direct Optical Detectior } \\
\text { with guest editors Antje J. Baeumner, Günter Gauglitz, and Jiri Homola }\end{array}$} \\
\hline \multicolumn{3}{|c|}{$\begin{array}{l}\text { Michael Seidel } \\
\text { michael.seidel@mytum.de }\end{array}$} \\
\hline \multicolumn{3}{|c|}{$\begin{array}{l}\text { Institute of Hydrochemistry, Chair of Analytical Chemistry and } \\
\text { Water Chemistry, Technical University of Munich, } \\
\text { Marchioninistraße 17, } 81377 \text { Munich, Germany }\end{array}$} \\
\hline \multicolumn{3}{|c|}{$\begin{array}{l}\text { Faculty of Biology and Signalling Research Centres BIOSS and } \\
\text { CIBSS, University of Freiburg, Schänzlestraße 18, } \\
79104 \text { Freiburg, Germany }\end{array}$} \\
\hline
\end{tabular}

$\begin{array}{ll}\text { IgG } & \text { Immunoglobulin G } \\ \text { LoD } & \text { Limit of detection } \\ \text { MCR 3 } & \text { Microarray Chip Reader (3rd generation) } \\ \text { MIPs } & \text { Molecularly imprinted polymers } \\ \text { MTP } & \text { Microtiter plate } \\ \text { OTC } & \text { Oxytetracycline } \\ \text { PEG } & \text { Polyethylene glycol } \\ \text { POM } & \text { Polyoxymethylene } \\ \text { SA-HRP } & \text { HRP-conjugated streptavidin } \\ \text { SDS } & \text { Sodium dodecyl sulfate } \\ \text { SPR } & \text { Surface plasmon resonance } \\ \text { TC } & \text { Tetracycline derivative } \\ \text { TET } & \text { Tetracycline } \\ \text { tetO } & \text { Tetracycline operator DNA sequence } \\ \text { TetR } & \text { Tetracycline repressor protein } \\ \text { TetA } & \text { Tetracycline efflux protein } \\ \text { Tris } & \text { Tris(hydroxymethyl)aminomethane }\end{array}$

\section{Introduction}

TCs are natural or semisynthetic antibiotics that act against a wide range of gram-positive and gram-negative bacteria and 
other microorganisms $[1,2]$. They are the most common veterinary antibiotics worldwide [3], such as in 2016, $5.9 \mathrm{kt} \mathrm{TCs}$ were sold in the USA and $2.5 \mathrm{kt}$ in Europe (42\% and $32 \%$ of the veterinary antibiotic sales amount, respectively) $[4,5]$. Various livestock breeds as poultry, cattle, swine, and sheep as well as aquacultures are treated with TCs to prevent or cure microbial infections and, in many countries, they are also used as growth promotors $[2,6,7]$. To attend whole herds, the drug is directly added to feed or water or even spread by aerosols [2]. In human medicine, TCs are mainly applied to treat atypical pneumonia, chlamydial infections, acute $\mathrm{Q}$ fever, and acne vulgaris [1]. Due to the low costs, TCs are particularly relevant for economically weak regions of the world [2]. Over the past decades, the number of TC-resistant bacterial strains drastically increased, so the ubiquitous presence of TCs and TC-resistant bacteria is an issue of public health $[2,8]$.

The TCs administered in animal husbandry are released into the environment via excretion and using the excrements as manure on the fields. So TCs have already been found in various environmental samples. Due to their chelating ability, TCs are mainly accumulated in soil fertilized with manure or in sediment but have also been detected in surface waters [9, 10]. Remarkably high maximum concentrations were found in arable soil, e.g., in northern China (OTC $2700 \mu \mathrm{g} \mathrm{kg}^{-1}$ ) [11], northern Germany (TET $307 \mu \mathrm{g} \mathrm{kg}^{-1}$ ) [12], and South Korea (TET $178 \mu \mathrm{g} \mathrm{kg}^{-1}$ ) [13]. In surface waters, high concentrations were detected in South Korea (TET $255 \mu \mathrm{g} \mathrm{L}^{-1}$ ) [13], China (OTC $73 \mu \mathrm{g} \mathrm{L}^{-1}$ ) [14], Japan (OTC $68 \mu \mathrm{g} \mathrm{L}^{-1}$ ) [15], and USA (OTC $1.3 \mu \mathrm{g} \mathrm{L}^{-1}$ ) [16]. For detailed reviews of multiple studies, it is referred to $[3,9]$.

The most common confirmatory method for the analysis of TCs is HPLC-MS [8, 17]. Disadvantages are high costs of apparatus and supplies, complex sample preparation, and the need for skilled personnel $[17,18]$. For an extensive monitoring of TC residues in environmental and food samples, costefficient and easy-to-handle high-throughput screening methods with low detection limits are required [17, 19]. Microbiological inhibition tests are very common screening methods for the detection of various antimicrobial substances [17]. The growth of test microorganisms is inhibited when antibiotics are present [20]. Some advantages are simplicity and low costs as well as the possibility to detect any substance with antimicrobial activity $[17,18]$. Therefore, several commercial test kits are available as screening methods for food analyses [17]. Though, these inhibition tests are with several hours very time-consuming and non-selective [17, 18]. An advanced method in biosensor format detected the inhibition of bacterial growth based on decreasing $\mathrm{CO}_{2}$ production at a concentration level of $25 \mu \mathrm{g} \mathrm{L}^{-1}$ TCs in milk within $120 \mathrm{~min}$ [21]. Immunoassays are, in general, widely established in routine analysis due to their high sensitivity and selectivity combined with cost efficiency and simplicity $[17,18]$. A selective antibody reacts with an antigen which is normally a characteristic section of a substance or a class of substances $[17,19]$. Prior to this work, a flow-based microarray with regenerable indirect competitive CL immunoassays for the simultaneous detection of 13 antibiotics has successfully been established [22]. For the purpose of a competitive TC assay, however, it was not possible to stably immobilize a TC derivative that would have been regenerable over several measurements. Due to the complex functionality and the high reactivity of TCs, coupling a TC derivative to a carrier protein for antibody production is also quite difficult, so there are only few immunoassay methods reported for the detection of TCs [23]. Instead of antibodies, in vitro produced biomimetic receptors as MIPs and aptamers are promising tools for biosensors [19].

A wide range of antibiotic analysis methods using proteins as bioreceptors is already established. These naturally occurring proteins are selective for a certain class of substances which means that they do not distinguish between different derivatives of e.g. TCs but can be used for comprising detection of the respective antibiotic class [18]. For analytic application, either whole cells containing the receptor protein are directly used or the protein is isolated. Furthermore, the receptor protein can easily be expressed recombinantly in bacteria which is a clear advantage compared to antibodies [18]. Suitable proteins are either the target protein of the antibiotic activity in the bacterial cell or a protein that is part of the bacterial resistance mechanism of resistant bacteria. For TC detection, the repressor protein TetR that is found in TCresistant bacteria can be used [24]. TetR binds specifically to a DNA sequence $(t e t O)$ and therefore inhibits the expression of the TC efflux protein TetA. Binding of TC to TetR leads to a conformational change of the receptor protein so that it releases the DNA and the efflux protein TetA is produced [25]. TetR has already been established in some analytical applications. Commercially available are e.g. SNAP (enzyme-labeling receptor assay), Charm II (radio receptor assay), and Tetrasensor (colloidal gold receptor assay) [18].

Receptor-based assays for TC detection are summarized in Table 1. First, there are several static assays (a) - (e). A wholecell biosensor based on the TC-resistant Escherichia coli strain TetLux was developed for the detection of TCs in MTPs (a). The cells contained a plasmid featuring a bacterial luciferase operon that was regulated together with tetO. Therefore, binding of TC to TetR led to the expression of the luciferase and the bioluminescence could be detected [26]. In a competitive MTP receptor assay (b), HRPconjugated TET was used to compete with TCs in the sample for immobilized TetR [27]. Competitive assays with immobilized tet $O$ were also established. A dipstick test on membrane strips (c) was based on His $_{6}$-tagged TetR that was released from tet $O$ in presence of TCs. The remaining TetR was marked with anti-His ${ }_{5}$ antibody and HRP-labeled antiIgG antibody and the detection was carried out by means of 
Table 1 Bioassays for the detection of TCs using TetR as receptor protein

\begin{tabular}{|c|c|c|c|c|c|c|}
\hline Assay principle & $\begin{array}{l}\text { Detection } \\
\text { method }\end{array}$ & Matrices & $\begin{array}{l}\mathrm{LoD} / \\
\mu \mathrm{g} / \mathrm{L}\end{array}$ & Analysis time & $\begin{array}{l}\text { Regenerable } \\
\text { sensor? }\end{array}$ & Ref \\
\hline \multicolumn{7}{|l|}{ Static assays } \\
\hline (a) Whole-cell biosensor in MTP & Bioluminescence & $\begin{array}{l}\text { Poultry } \\
\text { meat }\end{array}$ & $25 \mu \mathrm{g} / \mathrm{kg}$ & $4 \mathrm{~h}$ & No & {$[26]$} \\
\hline $\begin{array}{l}\text { (b) TetR immobilized in MTP, TET-HRP as } \\
\text { competitor }\end{array}$ & $\mathrm{CL}$ & Milk & $8 \mathrm{ng} / \mathrm{L}$ & $\begin{array}{l}2 \mathrm{~h} \\
(+ \text { coating })\end{array}$ & No & {$[27]$} \\
\hline (c) tetO immobilized on membrane strips & Color reaction & $\begin{array}{l}\text { Milk, meat, } \\
\text { serum }\end{array}$ & $5-10$ & $\begin{array}{l}1 \mathrm{~h} \\
(+ \text { dipstick } \\
\quad \text { production })\end{array}$ & No & {$[28]$} \\
\hline (d) tetO immobilized on MTP & Color reaction & $\begin{array}{l}\text { Milk, bovine } \\
\text { serum }\end{array}$ & 1.9 & $\begin{array}{l}\text { Several hours } \\
\text { (+ coating) }\end{array}$ & No & {$[24]$} \\
\hline (e) tetO immobilized on MTP & Bioluminescence & Tris buffer & 0.05 & $\begin{array}{l}2 \mathrm{~h} \\
(+ \text { coating })\end{array}$ & No & [29] \\
\hline \multicolumn{7}{|l|}{ Flow-based assays } \\
\hline (f) tet $O$ immobilized on chip & Electric current & Human plasma & 6.3 & $15 \min$ & No & {$[30]$} \\
\hline (g) DOX immobilized on chip as competitor & SPR & HBS-P buffer & - & ca. $15 \mathrm{~min}$ & Poorly & {$[31]$} \\
\hline (h) tetO immobilized on chip & SPR & $\begin{array}{l}\text { HBS-P buffer } \\
\text { Milk (needs } \\
\text { pretreatment) }\end{array}$ & $\begin{array}{l}1 \\
15\end{array}$ & ca. $10 \mathrm{~min}$ & Yes & {$[32]$} \\
\hline (i) tetO covalently immobilized on chip & CL & Tap water & 0.1 & $30 \mathrm{~min}$ & Yes & New \\
\hline
\end{tabular}

a color reaction [28]. Using tetO immobilized in MTPs, some ELISA-type assays were performed, e.g., with $\mathrm{His}_{6}$-tagged TetR, anti-His ${ }_{5}$ antibody, HRP-labeled anti-mouse antibody, and color reaction [24] or luciferase-tagged TetR and luminescence [29]. In general, these static assays are quite easy to perform. However, they are time-consuming and there is no possibility for online integration, assay regeneration or multiplexing for the simultaneous detection of several analytes.

Furthermore, some flow-based methods (f) - (h) have been reported. A competitive assay with tet $O$ immobilized on an electrochemical microfluidic polymer chip (f) was established. The sample was mixed with biotinylated TetR and avidin-glucose oxidase and flushed over the chip. The electrochemical signal of glucose oxidation was detected. This method can be multiplexed on a small scale as the microfluidic platform can process up to eight assays simultaneously. However, the biosensor is designed for single use and cannot be regenerated [30]. Assays with SPR detection, e.g., on Biacore platform, are basically regenerable. However, for an assay with immobilized DOX as competitor (g) it turned out that the signal intensity continued to decrease significantly with each regeneration step. The sensitivity of this method was not directly stated, but it seemed to be in the range of $20-100 \mu \mathrm{g} \mathrm{L}^{-1}$ [31]. The only regenerable assay was found to be the SPR (Biacore) assay with tetO immobilized via biotin tag on a streptavidin surface (h) [32]. The disadvantages of this method are the need for sample pretreatment due to matrix sensitivity and that a simultaneous processing of different assays on the same chip is not possible.
For a fully automated on-site monitoring of several contaminants in environmental or sewage water samples, however, both multiplexing and reusability of the sensor are absolutely required. In our work, as described in Fig. 1, a double-stranded DNA oligonucleotide including the specific operator sequence tet $O$ is covalently immobilized by an amino-C12 tag to a functionalized surface (a silanized and Jeffamine ${ }^{\circledR}$-coated glass slide activated with poly(ethylene glycole) diglycidyl ether) [33]. On the microfluidic chip formed from this glass slide, a mixture of biotin-labeled TetR solution and the sample is incubated so that TC from the sample can trigger a conformational change in TetR to dissociate from immobilized tetO. The amount of TetR that is bound to immobilized tet $O$ is marked with HRP-labeled streptavidin and the detection is achieved via HRP-catalyzed CL due to its generally high sensitivity that has already been shown for immunoassays [34, 35]. The described method presented in this work (i) is highly sensitive, robust against surface water, regenerable for at least 9 measurements, and it can easily be combined in future with various other receptor or immunoassays in a multiplex chip format.

\section{Materials and methods}

Unless otherwise stated, all standard chemicals and materials were purchased from Sigma-Aldrich (Taufkirchen, Germany) or Carl Roth (Karlsruhe, Germany). 


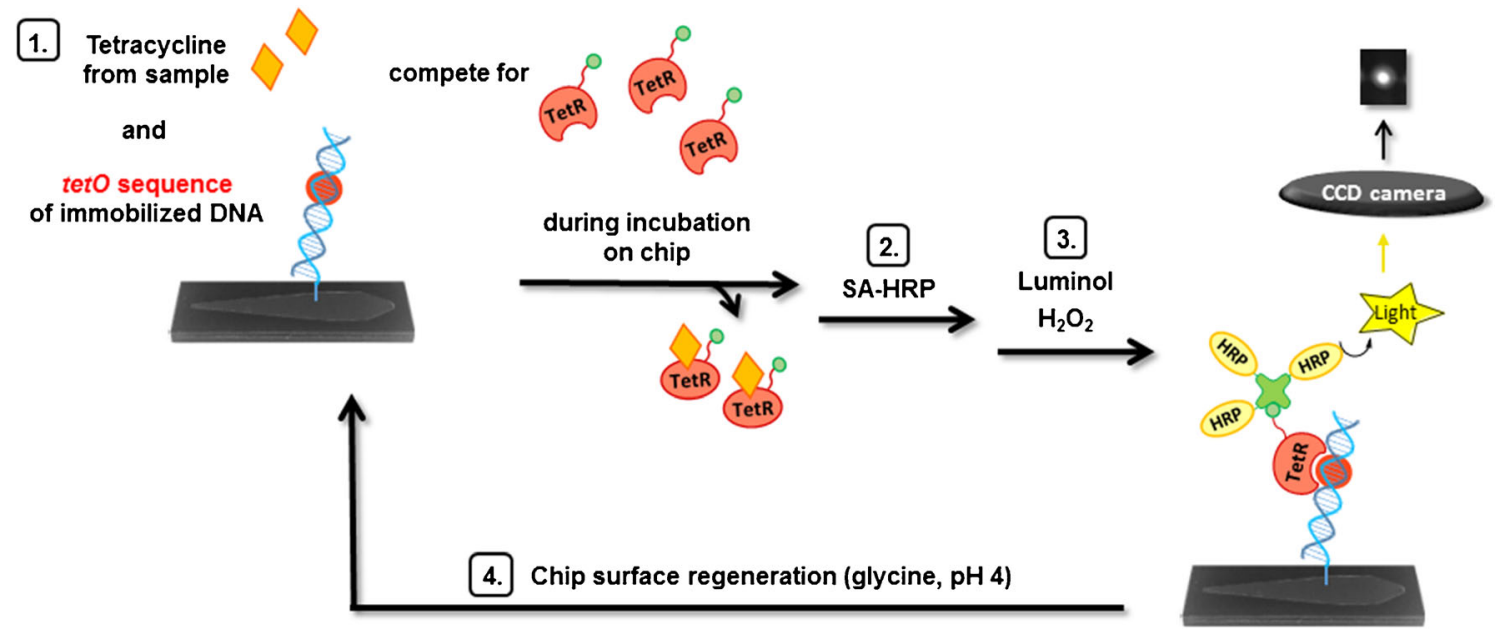

Fig. 1 Scheme of the flow-based regenerable competitive CL assay for the detection of TCs with TetR as receptor and the immobilized DNA oligonucleotide containing the specific operator sequence $t e t O$ as competitor

\section{Repressor protein production and purification}

The repressor protein TetR was produced with a C-terminal Avitag for in vivo site specific biotinylation by the enzyme BirA, followed by a $\mathrm{His}_{6}$ tag for purification as described elsewhere [30]. In brief, E. coli BL21* (DE3) were cotransformed with plasmids pCVC008 and pBirA for coexpression of biotinylated TetR protein and BirA enzyme, respectively. Cells were grown in LB medium supplemented with ampicillin $\left(100 \mu \mathrm{g} \mathrm{mL} \mathrm{m}^{-1}\right)$ and chloramphenicol $\left(34 \mu \mathrm{g} \mathrm{mL}^{-1}\right)$ at $37^{\circ} \mathrm{C}$ until $\mathrm{OD}_{600}=0.6$. The culture medium was supplemented with $50 \mu \mathrm{M}$ biotin and protein production was induced with $1 \mathrm{mM} \beta$-D-1-thiogalactopyranoside overnight at $20^{\circ} \mathrm{C}$. Cells were harvested by centrifugation $(6000 \times \mathrm{g}, 10 \mathrm{~min}$ at room temperature), resuspended in lysis buffer $(35 \mathrm{~mL}$ per liter initial culture volume, $50 \mathrm{mM}$ $\mathrm{NaH}_{2} \mathrm{PO}_{4}, 300 \mathrm{mM} \mathrm{NaCl}, 10 \mathrm{mM}$ imidazole, $\mathrm{pH}$ 8.0), freeze-thawed and lysed by sonication (Bandelin, Berlin, Germany; $60 \%$, pulse $0.5 \mathrm{~s}$ every second for $10 \mathrm{~min}$ ). Subsequently, cell debris were eliminated by centrifugation $\left(30,000 \times g, 30 \mathrm{~min}\right.$ at $\left.4{ }^{\circ} \mathrm{C}\right)$. Proteins were purified from the supernatant on a gravity flow $\mathrm{Ni}^{2+}$-NTA-agarose Superflow column (Qiagen, Hilden, Germany) following manufacturer instructions. Protein concentration was determined by the Bradford method (Bio-Rad, Hercules, USA) using BSA as standard. Proteins were diluted to $1 \mathrm{mg} \mathrm{mL}^{-1}$ in elution buffer $\left(50 \mathrm{mM} \mathrm{NaH} \mathrm{PO}_{4}, 300 \mathrm{mM} \mathrm{NaCl}, 250 \mathrm{mM}\right.$ imidazole, $\mathrm{pH}$ 8.0) containing $10 \%(\mathrm{w} / \mathrm{v})$ sucrose, lyophilized and stored at $-80^{\circ} \mathrm{C}$. For each experiment, the lyophilized proteins were reconstituted in $\mathrm{H}_{2} \mathrm{O}$.

The biotinylation motif was fused to the $\mathrm{C}$-terminus of the TetR protein as this site was previously shown to support different fusion partners while not influencing DNA-binding or responsiveness to tetracycline [36]. Stability of DNA- immobilized biotinylated TetR was demonstrated for at least 3 months at $4{ }^{\circ} \mathrm{C}[30]$.

\section{Chip surface chemistry}

The assay was performed on glass slides that were functionalized as described elsewhere [33]. In summary, microscopic glass slides were extensively cleaned and acidly activated for the following silanization with (3-glycidyloxypropyl)trimethoxysilane. The silanized carriers were then coated with Jeffamine ${ }^{\circledR}$ ED2003, supplied as a sample by Huntsman (Everberg, Belgium), and the terminal amino groups reacted with the epoxy groups of poly(ethylene glycole) diglycidyl ether to form a robust PEG layer with epoxy groups as active binding sites for the immobilization of the oligonucleotide $t e t O$.

\section{Annealing of the double-stranded oligonucleotide tetO}

The double-stranded DNA operator tet $O$ that can bind the repressor protein TetR was generated by mixing the oligonucleotides amino-C12-GCACTCCCTATCAGTGATAG AGAAACG and CGTTTCTCTATCACTGATAGGGAGTG C (both produced by Eurofins Genomics, Ebersberg, Germany) in equimolar amounts $(100 \mu \mathrm{M} / 200 \mu \mathrm{M} / 400 \mu \mathrm{M})$ in PCR-grade ultrapure water. The mixtures were incubated at $95^{\circ} \mathrm{C}$ for $5 \mathrm{~min}$, followed by controlled cooling $\left(2^{\circ} \mathrm{C} \mathrm{min}^{-1}\right)$ to room temperature.

\section{Microfluidic chip preparation}

The annealed oligonucleotides were transferred to the functionalized glass slides using the micro-contact spotter BioOdyssey Calligrapher® MiniArrayer from Bio-Rad 
(Hercules, USA) equipped with a solid pin SNS 9 from ArrayIT (Sunnyvale, USA). Each solution was spotted in five replicates with a grid spacing of $1100 \mu \mathrm{m}$ for the rows and $1300 \mu \mathrm{m}$ for the columns. The spotting process was carried out at $20^{\circ} \mathrm{C}$ and $50 \%$ humidity.

During overnight incubation $\left(25{ }^{\circ} \mathrm{C}, 50 \%\right.$ humidity), the oligonucleotides were covalently immobilized via their amino-C12 tags reacting with the terminal epoxy groups of the PEG layer. Remaining binding sites of the surrounding surface were afterwards inactivated with blocking buffer (1 M Tris, $150 \mathrm{mM}$ sodium chloride, $\mathrm{pH} 8.5,15 \mathrm{~min}$ ).

The flow cell was assembled by connecting the spotted glass slide to a POM sheet (thickness $1 \mathrm{~mm}$ ) by means of a double-sided adhesive tape ARCare ${ }^{\circledR} 90106$ from Adhesive Research (Glen Rock, USA) with cutouts forming two flow channels (due to the connections in the MCR 3; only one flow channel was used for this work). Inlet and outlet holes in the POM sheet enabled the passage of fluids. The ready-to-use chips (see Fig. 2) were stored at $-20^{\circ} \mathrm{C}$.

\section{Measurement setup}

The assay was automatically processed by the MCR 3 from GWK Präzisionstechnik (Munich, Germany). The MCR 3 comprises a flow channel for inserting the microfluidic chip, integrated pumps, valves, and tubing for supplying reagents, and a CCD camera for chemiluminescence readout [37]. Assay protocols can be defined and run by the software MCR Visu 1.0.6.2 (GWK Präzisionstechnik, Munich, Germany).

$0.5 \%(\mathrm{w} / \mathrm{v})$ casein in PBS $(10 \mathrm{mM}$ potassium dihydrogen phosphate, $70 \mathrm{mM}$ dipotassium hydrogen phosphate, $145 \mathrm{mM}$ sodium chloride) was used as running buffer. The regeneration buffer (100 mM glycine, $100 \mathrm{mM} \mathrm{NaCl}$, and $0.1 \%$ (w/v) SDS, adjusted to $\mathrm{pH} 4$ ) was applied in the last step for removing the bound bio-reagents from the immobilized oligonucleotides.

The biotinylated TetR protein and SA-HRP were diluted in running buffer to a concentration of $0.2 \mathrm{mg} \mathrm{L}^{-1}$ and $0.15 \mathrm{mg} \mathrm{L}^{-1}$, respectively (stock concentrations $0.6 \mathrm{mg} \mathrm{mL}^{-1}$ and $1 \mathrm{mg} \mathrm{mL}^{-1}$ ).

For the chemiluminescence reaction, ready-to-use luminol and hydrogen peroxide solutions from the Elistar Supernova Elisa kit (Cyanagen, Bologna, Italy) were adopted.

All the solutions were filled into the respective reservoirs of the MCR 3 and the tubes were automatically loaded to get ready for measurements.

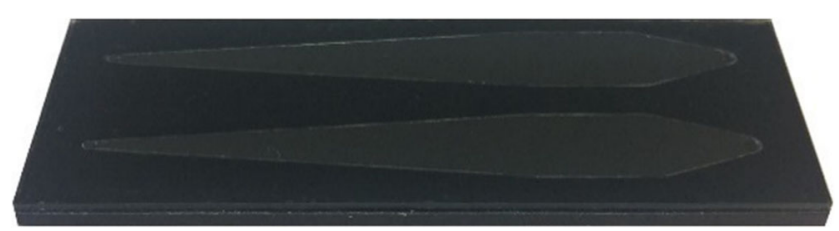

Fig. 2 Ready-to-use microfluidic chip (flow direction from left to right)
PBS containing $50 \mathrm{mM} \mathrm{MgCl}$ was used as blank sample for measuring the maximum signal intensities. For calibration experiments, TET was diluted in PBS containing $50 \mathrm{mM}$ $\mathrm{MgCl}_{2}$ to defined concentrations ( 0.01 to $\left.1000 \mu \mathrm{g} \mathrm{L}{ }^{-1}\right)$.

The measurement protocol started with mixing the sample with the TetR solution (1:1) and injecting this mixture into the flow channel of the microfluidic chip. For this step, three different methods were examined: (1) automated mixing by means of the MCR 3 and pumping $400 \mu \mathrm{L}$ slowly through the flow channel $\left(10 \mu \mathrm{L} \mathrm{s}^{-1}\right)$; (2) stop-flow, pumping each $50 \mu \mathrm{L}$ of the automated mixed solution slowly in the flow channel $\left(10 \mu \mathrm{L} \mathrm{s}^{-1}\right)$, stop $60 \mathrm{~s}$, repeat the sequence 8 times; (3) manually mixing and injecting $50 \mu \mathrm{L}$ in the flow channel, incubating for a certain time (10-120 $\mathrm{min})$ and at a defined temperature $\left(18-46^{\circ} \mathrm{C}\right)$ outside the MCR 3 .

All the following steps were, again, carried out by means of the MCR 3 at a defined temperature $\left(18\right.$ or $\left.37^{\circ} \mathrm{C}\right)$. After cleansing with running buffer $(2000 \mu \mathrm{L}$ with a flow rate of $100 \mu \mathrm{L} \mathrm{s}^{-1}$ ), the SA-HRP solution was slowly flushed through the flow channel $\left(800 \mu \mathrm{L}\right.$ with a flow rate of $\left.10 \mu \mathrm{L} \mathrm{s}{ }^{-1}\right)$, followed by another cleansing step $(2000 \mu \mathrm{L}$ with a flow rate of $100 \mu \mathrm{L} \mathrm{s}^{-1}$ ). A mixture of each $200 \mu \mathrm{L}$ of hydrogen peroxide and luminol was flushed through the flow channel $\left(100 \mu \mathrm{L} \mathrm{s}^{-1}\right)$. The flow was stopped, and the chemiluminescence was recorded by the CCD camera for $60 \mathrm{~s}$. Subsequently, the whole fluidic system was extensively rinsed with running buffer, and the flow channel was treated with regeneration buffer $\left(1000 \mu \mathrm{L}\right.$ with a flow rate of $\left.10 \mu \mathrm{L} \mathrm{s}^{-1}\right)$, followed by a final cleansing step $(2000 \mu \mathrm{L}$ with a flow rate of $500 \mu \mathrm{L} \mathrm{s}^{-1}$ ). Thus, the chip was ready for the next measurement.

The key steps of the established measurement setup are summarized in Table 2.

\section{Data analysis}

The detected CL signals were processed with the image evaluation software MCR Image Analyzer 0.3.2.1 (GWK Präzisionstechnik, Munich, Germany).

At the beginning of a measurement day, the background signal of the CCD camera was recorded and then subtracted from each newly recorded CL image. Using the backgroundcorrected CL images, the ten brightest pixels of each spot were averaged. The mean and standard deviation of the five equivalent spots in a row were calculated, excluding spots that deviated more than $20 \%$ from the mean. Unspecific CL intensity of the non-spotted chip surface was subtracted from the thus calculated mean values.

To normalize the calibration curves, relative signal intensities $B / B_{0}$ (in \%) were calculated by dividing the signal intensity of a certain TET concentration by the maximum signal intensity obtained in the calibration series (that was set to $100 \%)$. 


\section{Analysis of real surface water samples}

Nine surface water samples from three sampling sites in the surroundings of a chicken farm in Wullwinkel, Brandenburg, Germany, were collected. After decantation and filtration with syringe filters (pore sizes of 0.8 and $0.22 \mu \mathrm{m}$ ), the samples were directly analyzed.

\section{Results and discussion}

The aim of setting up the assay to gain high and consistent CL signal intensities at the tet $O$ spots and low unspecific background. Due to the competitive assay principle, maximum signal intensities were obtained in the absence of TCs. Therefore, the assay characterization was firstly carried out with blank samples and the displayed CL signals were always calculated from the tet $O$ signals minus the background intensities.

The decisive factors for the intensities and the reproducibility of the signals were the interaction time for the competition reaction, the temperature during this interaction, the temperature of the following measurement steps, and the DNA oligonucleotide spotting concentration. However, the regenerability was also affected by these parameters, so a systematic investigation was carried out.

\section{Setup of the competition reaction}

In the first step of the assay, the immobilized DNA operator tet $O$ and possibly present $\mathrm{TC}$ from the sample compete for the receptor protein TetR. For implementing this step, there are three feasible ways to incubate the sample/TetR mixture with immobilized tet $O$ : flushing the mixture slowly but constantly through the microfluidic cell, using a stop-flow sequence or a static incubation for an extended time. Compared to a constant

Table 2 Key steps of the established measurement setup

Measurement steps
1. Manual mixing of sample and TetR solution (each $30 \mu \mathrm{L})$
2. Injecting $50 \mu \mathrm{L}$ of the mixture into the microfluidic chip,
incubating for a certain time $(10-120$ min) and at a defined
temperature $\left(18-46^{\circ} \mathrm{C}\right)$
3. Inserting the chip into the MCR 3 (defined measurement
temperature, 18 or $37^{\circ} \mathrm{C}$ )
4. Slowly flushing SA-HRP through the flow channel
( $800 \mu \mathrm{L}$, flow rate $\left.10 \mu \mathrm{L} \mathrm{s})^{-1}\right)$
5. Flushing a $1: 1$ mixture of hydrogen peroxide and luminol
through the flow channel (each $200 \mu \mathrm{L}$, total flow rate $100 \mu \mathrm{L} \mathrm{s}{ }^{-1}$ )
6. Recording CL with CCD camera for $60 \mathrm{~s}$
7. Regenerating tet $O$ on the chip surface with regeneration buffer
( $1000 \mu \mathrm{L}$, flow rate: $10 \mu \mathrm{L} \mathrm{s}{ }^{-1}$ )

flow $\left(10 \mu \mathrm{L} \mathrm{s}^{-1}\right)$ at $18{ }^{\circ} \mathrm{C}$, the stop-flow method with eight increments, each incubated for $1 \mathrm{~min}$, increased the signal intensities by a factor of 2.5 , and a static incubation for $5 \mathrm{~min}$ or $15 \mathrm{~min}$ achieved an increase by a factor of 15 or 25 , respectively. While a constant flow had worked for immunoassays [22], the binding of the receptor protein to the double-stranded DNA oligonucleotide obviously required more interaction time.

Thus, the static incubation method was set for further investigations. For practical reasons, the sample/TetR mixture was manually injected in the flow channel of the microfluidic chip and the incubation was performed in an external incubator before the further steps of the assay took place in the MCR 3. Thereby, much less sample and TetR solution was needed per measurement ( $30 \mu \mathrm{L}$ instead of $500 \mu \mathrm{L}$, respectively), and the MCR 3 could be used for other measurements during the incubation time. In principle, however, fully automated processing of the whole assay in the MCR 3 would be possible as well. Due to requirements of other experiments that were conducted in the same incubator, 37 or $39^{\circ} \mathrm{C}$ was used for further experiments.

It was also demonstrated that a TET content in the sample led to a significant signal decrease (due to the competitive assay principle). Figure 3 shows the $C L$ images of samples with TET concentrations of $0 \mu \mathrm{g} \mathrm{L}^{-1}, 1 \mu \mathrm{g} \mathrm{L}^{-1}$, and $10 \mu \mathrm{g} \mathrm{L}^{-1}$.

\section{Regeneration of the chip surface}

A previous study had shown that the signal intensities of a CL assay with immobilized single-stranded DNA oligonucleotides for the detection of virus and phage DNA/RNA had been significantly increased by performing the entire assay at $40{ }^{\circ} \mathrm{C}$ instead of $20^{\circ} \mathrm{C}$ [38]. When performing the receptor assay for TC detection at $39^{\circ} \mathrm{C}$ instead of $18^{\circ} \mathrm{C}$, the signal intensities were increased by a factor of 4 . Since the competition reaction, the binding of streptavidin to biotin and the HRP catalysis are bioreactions as well, they were also more efficient at higher temperature.

An essential feature of this new method, however, should be the regenerability of the double-stranded DNA oligonucleotides immobilized on the chip surface. After recording the signals of the $\mathrm{CL}$ reaction, the regeneration was induced by a shift to $\mathrm{pH} 4$ which should change the conformation of the TetR-biotin/SAHRP complex and thus detach it from the DNA double strand. To evaluate the regenerability of the chip, eight measurements were consecutively carried out at $39^{\circ} \mathrm{C}$ (with 20 min incubation of the sample/TetR mixture for each measurement). As shown in Fig. 4a, the resulting CL signal intensities decreased drastically with progressing number of measurements on the same chip. After eight measurements, the remaining signal intensities for DNA spotting concentrations of $200 \mu \mathrm{M}$ and $100 \mu \mathrm{M}$ amounted to only $12 \%$ and $11 \%$ of the first measurement, respectively. The signal loss might be due to the fact that radicals formed from $\mathrm{H}_{2} \mathrm{O}_{2}$ during the $\mathrm{CL}$ reaction caused DNA damages based on DNA base oxidation and consecutive break of the double strand 


\section{DNA spotting concentration:}
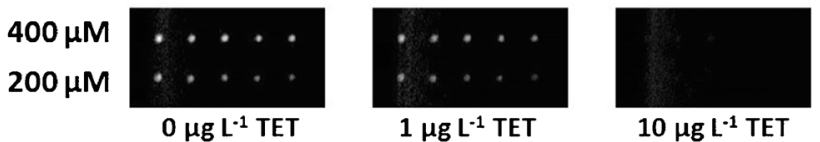

Fig. $3 \mathrm{CL}$ images of samples with different TET concentrations. The sample/TetR mixtures were incubated for 30 min at $37{ }^{\circ} \mathrm{C}$, the following measurement steps in the MCR 3 were carried out at $18{ }^{\circ} \mathrm{C}$

$[39,40]$. Therefore, the specific DNA operator might have been destructed and no longer been available for the next measurements. Since the radical yield increases with temperature [40], the CL reaction step would be less damaging at lower temperature.

As a promising alternative, the sample/TetR mixture was still incubated at $39{ }^{\circ} \mathrm{C}$ whereas the following measurement steps were all conducted at $18^{\circ} \mathrm{C}$. A sequence of nine blank measurements was performed (with 20 min incubation of the sample/TetR mixture for each measurement). After each measurement with regeneration, it was proven in a further step that the surface had been restored to its original state and that there were no remaining signals. For this purpose, the chip was again treated with SA-HRP, followed by luminol and hydrogen peroxide, and another CL image was recorded. Figure $4 \mathrm{~b}$ shows the resulting CL signals of the sequence with intermediary proof-of-regeneration steps $(\mathrm{R})$.

Compared to the first measurement conducted at $39^{\circ} \mathrm{C}$, the signals amounted to only about one third. However, the signals remained almost constant over the nine measurements. For the DNA spotting concentrations of $400 \mu \mathrm{M}, 200 \mu \mathrm{M}$, and $100 \mu \mathrm{M}$, the signals obtained in the ninth measurement amounted to $81 \%, 87 \%$, and $83 \%$ of the signals measured at the beginning of the series, respectively. The coefficients of variation between the nine measurements were determined to be $8 \%, 5 \%$, and $9 \%$, respectively. Thus, the DNA spotting concentration of $200 \mu \mathrm{M}$ led to the highest regenerability and the lowest signal variations.

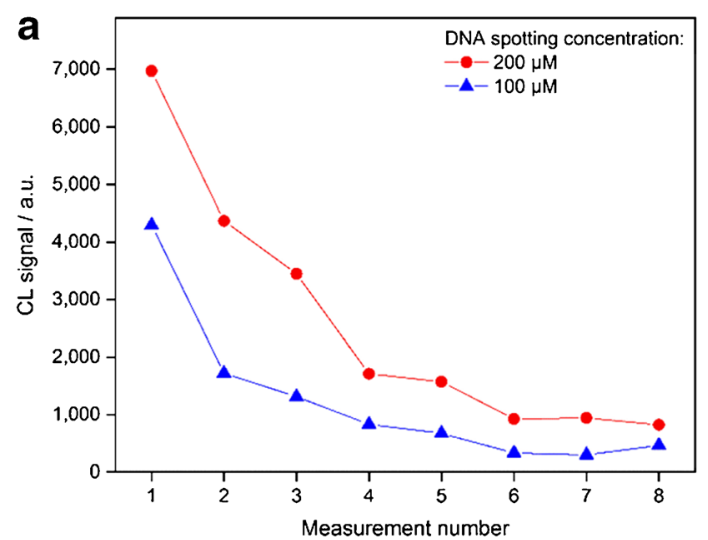

Fig. 4 CL signal intensities of consecutive measurements on the same chip. The sample/TetR mixture was each time incubated for $20 \mathrm{~min}$ at $39{ }^{\circ} \mathrm{C}$ and the following measurement steps in the MCR 3 were carried out at $39{ }^{\circ} \mathrm{C}$ (a) or $18{ }^{\circ} \mathrm{C}(\mathbf{b})$, which additionally shows the respective proof-of-regeneration steps $(\mathrm{R})$. As only the trends are relevant, the
The proof-of-regeneration steps $(\mathrm{R})$ showed only very low unspecific signals (less than one tenth of the respective measurement signal), remaining constant over the entire measuring sequence, so the repeated regeneration of the immobilized DNA oligonucleotides was successfully demonstrated.

\section{Influence of incubation time and temperature}

Using the static incubation method, time and temperature of the incubation step were varied to further investigate the influence on the signal intensities.

Eight different incubation times between 10 and $120 \mathrm{~min}$ were tested (with an incubation temperature of $39{ }^{\circ} \mathrm{C}$ and a temperature of $18^{\circ} \mathrm{C}$ for the following measurement steps). The resulting CL signal intensities are shown in Fig. 5a. Between 10 and $60 \mathrm{~min}$, there was a strong correlation of incubation time and CL signal intensity. For longer incubation times, the curves became flatter so that a further increase of the incubation time did not have a rewarding effect on the signal intensities. The incubation time for further experiments will always be a trade-off between analysis time and signal yield.

The incubation temperature was varied between 18 and $46^{\circ} \mathrm{C}$ in seven steps (with an incubation time of $15 \mathrm{~min}$ and a temperature of $18{ }^{\circ} \mathrm{C}$ for the following measurement steps). The resulting CL signal intensities are displayed in Fig. 5b. As TetR is a bioreceptor, the curves showed a maximum in the range of $40{ }^{\circ} \mathrm{C}$. At $46^{\circ} \mathrm{C}$, the $\mathrm{CL}$ signal intensities decreased significantly due to protein denaturation, so higher temperatures were not

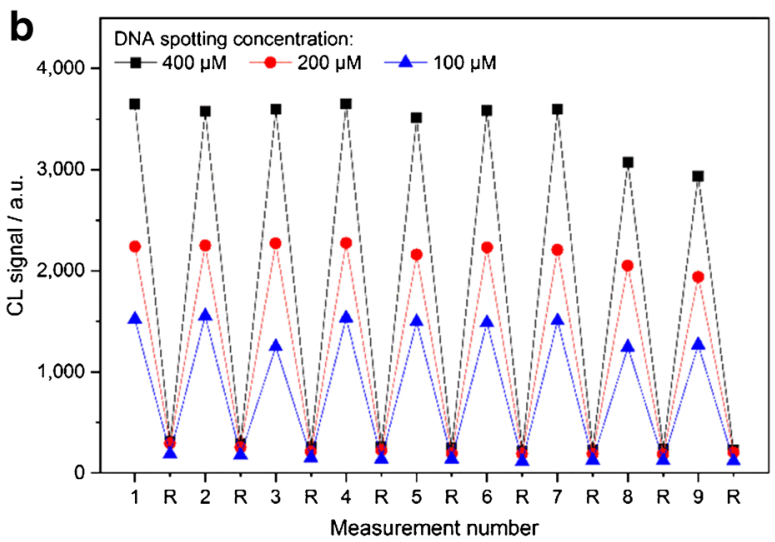

measurement sequences were conducted once. The points shown in the graphs correspond to the mean values of the five equivalent spots immobilized on the chip in a row, so that signal fluctuations were compensated 


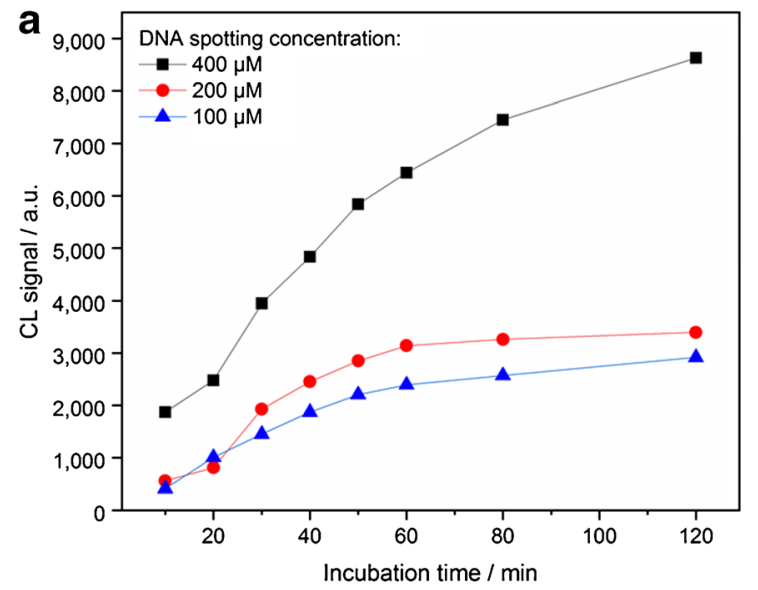

Fig. 5 Influence of incubation time (a) and temperature (b) on the CL signal intensities. The incubation time was varied with a constant temperature of $39^{\circ} \mathrm{C}$ (a) and the temperature was varied with an incubation time of $15 \mathrm{~min}$ (b). For both sequences, the following measurement steps in the MCR 3 were carried out at $18{ }^{\circ} \mathrm{C}$. As only

examined any more. Performing the competition reaction at biological relevant higher temperatures $\left(37-40^{\circ} \mathrm{C}\right)$ and the further measurement steps at lower temperature $\left(18^{\circ} \mathrm{C}\right)$ turned out to be an efficient concept for regenerable CL receptor assays with immobilized double-stranded DNA oligonucleotides.

\section{Calibration and recovery experiments}

To examine the sensitivity and reproducibility of the assay, six-point calibration series with TET concentrations from 0.1 to $1000 \mu \mathrm{g} \mathrm{L}^{-1}$ in tap water were measured on three different chips (with $30 \mathrm{~min}$ incubation of the sample/TetR mixture at $37^{\circ} \mathrm{C}$ for each measurement). The averaged data points and the sigmoidal regression curves are shown in Fig. 6. For the DNA spotting concentrations of $400 \mu \mathrm{M}$ and $200 \mu \mathrm{M}$, LoDs of $0.5 \mu \mathrm{g} \mathrm{L}^{-1}$ and $0.1 \mu \mathrm{g} \mathrm{L}^{-1}$ and working ranges (80-20\% $\mathrm{B} / \mathrm{B}_{0}$ ) of $0.6-8.1 \mu \mathrm{g} \mathrm{L}{ }^{-1}$ and $0.5-6.8 \mu \mathrm{g} \mathrm{L}{ }^{-1}$ were obtained, respectively. The lower LoD of $200 \mu \mathrm{M}$ DNA spotting concentration corresponds with the higher regenerability and the lower coefficient of variation that were determined in the regeneration experiment (see above).

For $1 \mu \mathrm{g} \mathrm{L}^{-1}$ TET spiked in tap water, recoveries of $80 \% \pm$ $19 \%$ and $77 \% \pm 16 \%$ for the DNA spotting concentrations of $400 \mu \mathrm{M}$ and $200 \mu \mathrm{M}$, respectively, were obtained.

\section{Analysis of real surface water samples}

The established method is generally applicable for the analysis of real surface water samples as we showed in the introduction that $\mathrm{TC}$ concentrations in the $\mu \mathrm{g} \mathrm{L}^{-1}$ range were found in regions with intensive livestock farming in Asia and USA. In Europe, however, such high concentrations had never been found so far, so no positive results were expected. Rather, the focus was on

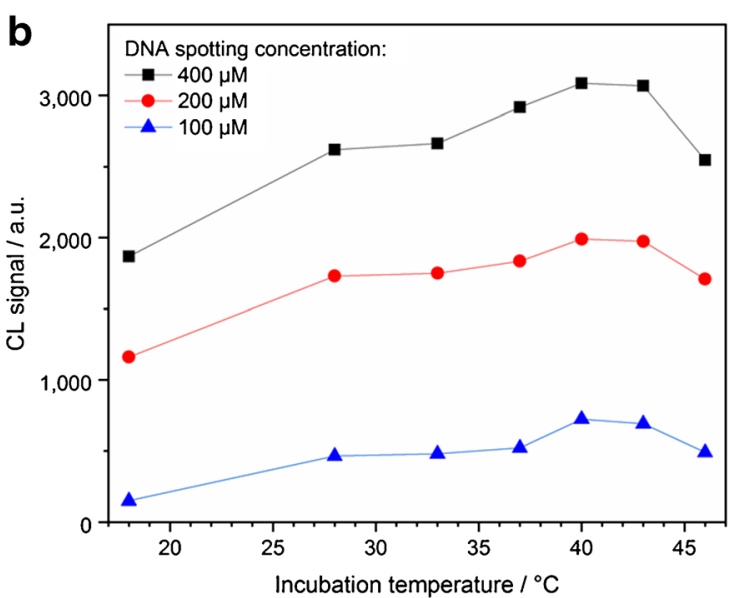

the trends are relevant, the measurement sequences were conducted once. The points shown in the graphs correspond to the mean values of the five equivalent spots immobilized on the chip in a row, so that signal fluctuations were compensated

investigating whether unspecific signal suppression by the complex real matrix occurs, which would lead to false-positive results.

Nine surface water samples from three sampling sites in the surroundings of a chicken farm in north-eastern Germany were analyzed (with $30 \mathrm{~min}$ incubation of the sample/TetR mixture at $37{ }^{\circ} \mathrm{C}$ for each measurement). Referring to nonspiked tap water, relative signal intensities of $97 \% \pm 9 \%$ for a DNA spotting concentration of $100 \mu \mathrm{M}$ and $91 \% \pm 8 \%$ for a DNA spotting concentration of $200 \mu \mathrm{M}$ were obtained, meaning that TCs were not detected in any sample. This result showed that signal suppression due to matrix effects did not occur and a pretreatment of the real samples was not required (except for filtration of suspended solids).

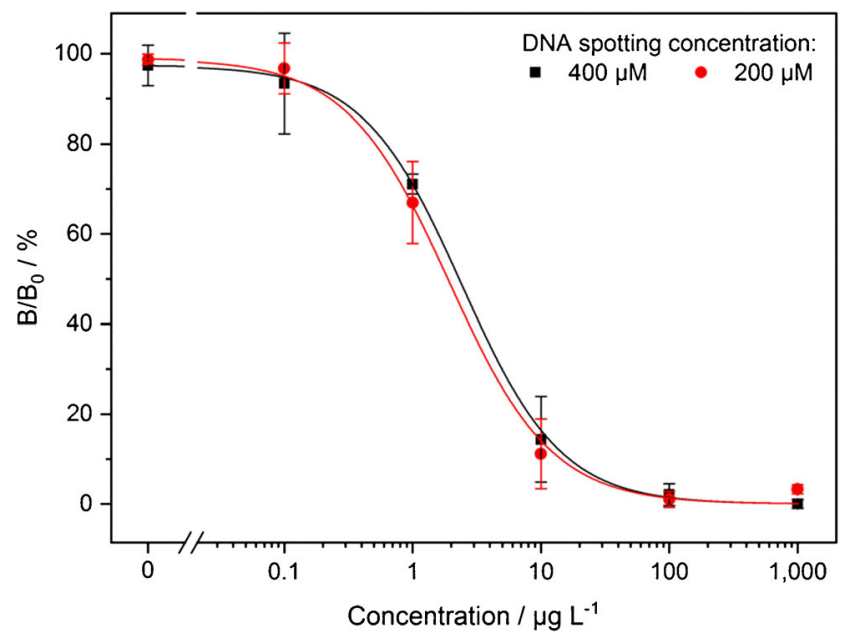

Fig. 6 Six-point calibration curves for TET, displayed as relative signal intensities $B / B_{0}$ (in \%) referring to the maximum measured signal of the respective series. Each data point represents the mean of three measurements (carried out on three different chips). The sample/TetR mixture was each time incubated for $30 \mathrm{~min}$ at $37{ }^{\circ} \mathrm{C}$, the following measurement steps in the MCR 3 were carried out at $18{ }^{\circ} \mathrm{C}$ 


\section{Conclusion and outlook}

The presented flow-based regenerable CL receptor assay for the detection of TCs proved to be highly sensitive and regenerable for many runs. The key parameters for high signal yield and regenerability were identified to be (1) the static incubation of the sample/TetR mixture in the flow channel for promoting the competition reaction and (2) the profile of a biologically relevant temperature $\left(37-40{ }^{\circ} \mathrm{C}\right)$ during the competition reaction and a lower temperature $\left(18^{\circ} \mathrm{C}\right)$ for the following measurement steps in order to avoid DNA damage. The incubation time will always be a trade-off between analysis time and signal yield and has therefore to be set concerning the demands of the respective application.

As the measurement protocol was developed based on the already established indirect competitive immunoassays for the multiplex detection of various antibiotics in milk [22] or honey [41] on the microarray analysis platform MCR 3, the concepts can evidently be combined. The future objective is to achieve a single microarray chip that can process multiple receptor and immunoassays in parallel. For competitive immunoassays, the antibiotics of interest can be immobilized besides the DNA oligonucleotides in separate rows on the chip. To perform the assays simultaneously, the corresponding primary antibodies are applied together with TetR (and possibly other receptor proteins) and the HRP-labeled secondary antibody together with streptavidin-HRP. A proof-of-principle study combined the TC receptor assay with some indirect competitive immunoassays. The measurements were performed with non-spiked tap water samples in the same way as it was optimized for only TC. When TetR and the primary antibodies were mixed, all the different spotted rows gave signals. When only TetR or the primary antibodies were applied, only the tet $O$ row or the respective antibiotic rows appeared. Thus, it was proven that there were no cross reactivities and that the combination is basically possible. A detailed study with calibrating all the assays, however, is very complex and effortful, so this will be the subject of further research.

In a future perspective, the monitoring of surface and sewage waters will become a major topic in environmental analysis [42, 43]. Quality requirements have already been specified, e.g., in the European Water Framework Directive (WFD) 2000/60/EC. An unsolved problem is that wastewater treatment plants are not yet able to completely remove micropollutants such as antibiotics from wastewater [44], so these compounds are drained in the environment. Furthermore, heavy rainfall events, which are increasing as a result of climate change [45, 46], mobilize micropollutants adsorbed to the soil and therefore flush them into surface waters [47]. In order not only to carry out isolated analyses, but also to ensure continuous monitoring, an online measuring device is required.

It has already been shown that the TC sensor works for real surface waters without pretreatment, although no TCs have been detected so far in a single sampling campaign in Germany. Profound studies in other countries will underline the efficiency of this innovative method. Both the multiplexing ability and the reusability make the sensor ideally suited for a fully automated monitoring of multiple contaminants in the field.

Acknowledgments Open Access funding provided by Projekt DEAL. We thank Thomas Dyhr for collecting the surface water samples in Wullwinkel, Brandenburg, Germany, and Julia Baaske for providing TetR.

Funding information This work was funded by Hanns Seidel Foundation. The work of Wilfried Weber was funded by the DFG (EXC-294 and EXC-2189—Project ID 390939984).

\section{Compliance with ethical standards}

Conflict of interest The authors declare that there are no conflicts of interest.

Open Access This article is licensed under a Creative Commons Attribution 4.0 International License, which permits use, sharing, adaptation, distribution and reproduction in any medium or format, as long as you give appropriate credit to the original author(s) and the source, provide a link to the Creative Commons licence, and indicate if changes were made. The images or other third party material in this article are included in the article's Creative Commons licence, unless indicated otherwise in a credit line to the material. If material is not included in the article's Creative Commons licence and your intended use is not permitted by statutory regulation or exceeds the permitted use, you will need to obtain permission directly from the copyright holder. To view a copy of this licence, visit http://creativecommons.org/licenses/by/4.0/.

\section{References}

1. Bahrami F, Morris DL, Pourgholami MH. Tetracyclines: drugs with huge therapeutic potential. Mini-Rev Med Chem. 2012;12(1):44-52.

2. Chopra I, Roberts M. Tetracycline antibiotics: mode of action, applications, molecular biology, and epidemiology of bacterial resistance. Microbiol Mol Biol Rev. 2001;65(2):232-60.

3. Charuaud L, Jarde E, Jaffrezic A, Thomas M-F, Le Bot B. Veterinary pharmaceutical residues from natural water to tap water: sales, occurrence and fate. J Hazard Mater. 2019;361:169-86.

4. European Medicines Agency (EMA). Sales of veterinary antimicrobial agents in 30 European countries in 2016. Trends from 2010 to 2016. Eighth ESVAC report (EMA/275982/2018). 2018.

5. U.S. Food \& Drug Administration (FDA), Center for Veterinary Medicine. 2017 summary report on antimicrobials sold or distributed for use in food-producing animals. 2018.

6. Kümmerer K. Antibiotics in the aquatic environment - a review part I. Chemosphere. 2009;75(4):417-34.

7. Gothwal R, Shashidhar T. Antibiotic pollution in the environment: a review. CLEAN - Soil, Air, Water. 2015;43(4):479-89.

8. Pérez-Rodríguez M, Pellerano RG, Pezza L, Pezza HR. An overview of the main foodstuff sample preparation technologies for tetracycline residue determination. Talanta. 2018;182:1-21.

9. Daghrir R, Drogui P. Tetracycline antibiotics in the environment: a review. Environ Chem Lett. 2013;11(3):209-27.

10. Burke V, Richter D, Greskowiak J, Mehrtens A, Schulz L, Massmann G. Occurrence of antibiotics in surface and groundwater 
of a drinking water catchment area in Germany. Water Environ Res. 2016;88(7):652-9.

11. Hu X, Zhou Q, Luo Y. Occurrence and source analysis of typical veterinary antibiotics in manure, soil, vegetables and groundwater from organic vegetable bases, northern China. Environ Pollut. 2010;158(9):2992-8.

12. Hamscher G, Sczesny S, Höper H, Nau H. Determination of persistent tetracycline residues in soil fertilized with liquid manure by highperformance liquid chromatography with electrospray ionization tandem mass spectrometry. Anal Chem. 2002;74(7):1509-18.

13. Awad YM, Kim S-C, Abd El-Azeem SAM, Kim K-H, Kim K-R, Kim K, et al. Veterinary antibiotics contamination in water, sediment, and soil near a swine manure composting facility. Environ Earth Sci. 2014;71(3):1433-40.

14. Wei R-C, Ge F, Chen M, Huang S-Y, Wang R. Pollution of tetracyclines from livestock and poultry farms in aquatic environment in Jiangsu Province, China. J Agro-Environ Sci. 2010;29(6):1205-10

15. Matsui Y, Ozu T, Inoue T, Matsushita T. Occurrence of a veterinary antibiotic in streams in a small catchment area with livestock farms. Desalination. 2008;226(1):215-21.

16. Lindsey ME, Meyer M, Thurman EM. Analysis of trace levels of sulfonamide and tetracycline antimicrobials in groundwater and surface water using solid-phase extraction and liquid chromatography/mass spectrometry. Anal Chem. 2001;73(19):4640-6.

17. Cháfer-Pericás C, Maquieira Á, Puchades R. Fast screening methods to detect antibiotic residues in food samples. TrAC Trends Anal Chem. 2010;29(9):1038-49.

18. Ahmed S, Ning J, Cheng G, Ahmad I, Li J, Mingyue L, et al. Receptor-based screening assays for the detection of antibiotics residues - a review. Talanta. 2017;166:176-86.

19. Gaudin V. Advances in biosensor development for the screening of antibiotic residues in food products of animal origin - a comprehensive review. Biosens Bioelectron. 2017;90:363-77.

20. Suhren G, Heeschen W. Detection of inhibitors in milk by microbial tests. A review. Food Nahrung. 1996;40(1):1-7.

21. Pellegrini GE, Carpico G, Coni E. Electrochemical sensor for the detection and presumptive identification of quinolone and tetracycline residues in milk. Anal Chim Acta. 2004;520(1):13-8.

22. Kloth K, Rye-Johnsen M, Didier A, Dietrich R, Martlbauer E, Niessner $\mathrm{R}$, et al. A regenerable immunochip for the rapid determination of 13 different antibiotics in raw milk. Analyst. 2009;134(7):1433-9.

23. Pastor-Navarro N, Maquieira Á, Puchades R. Review on immunoanalytical determination of tetracycline and sulfonamide residues in edible products. Anal Bioanal Chem. 2009;395(4):907-20.

24. Weber CC, Link N, Fux C, Zisch AH, Weber W, Fussenegger M. Broad-spectrum protein biosensors for class-specific detection of antibiotics. Biotechnol Bioeng. 2005;89(1):9-17.

25. Orth P, Schnappinger D, Hillen W, Saenger W, Hinrichs W. Structural basis of gene regulation by the tetracycline inducible Tet repressor-operator system. Nat Struct Biol. 2000;7:215.

26. Virolainen NE, Pikkemaat MG, Elferink JWA, Karp MT. Rapid detection of tetracyclines and their 4-epimer derivatives from poultry meat with bioluminescent biosensor Bacteria. J Agric Food Chem. 2008;56(23):11065-70.

27. Wang G, Zhang HC, Liu J, Wang JP. A receptor-based chemiluminescence enzyme linked immunosorbent assay for determination of tetracyclines in milk. Anal Biochem. 2019;564-565:40-6.

28. Link N, Weber W, Fussenegger M. A novel generic dipstick-based technology for rapid and precise detection of tetracycline, streptogramin and macrolide antibiotics in food samples. J Biotechnol. 2007;128(3):668-80.

29. Pellinen T, Rytkonen K, Ristiniemi N, Karp M, Lamminmaki U. Protein-DNA interaction-based detection of small molecules by employing Renilla luciferase fusion protein: quantitative and generic measurement of tetracyclines with a Renilla luciferasetagged Tet repressor protein. Anal Biochem. 2006;358(2):301-3.

30. Kling A, Chatelle C, Armbrecht L, Qelibari E, Kieninger J, Dincer $\mathrm{C}$, et al. Multianalyte antibiotic detection on an electrochemical microfluidic platform. Anal Chem. 2016;88(20):10036-43.

31. Andree U, Mueller-Seitz E, Usai I, Loeber S, Gmeiner P, Wimmer $\mathrm{C}$, et al. Tetracycline sensing using novel doxycycline derivatives immobilized on different surface plasmon resonance biosensor surfaces. Bioanal. 2010;2(2):217-27.

32. Moeller N, Mueller-Seitz E, Scholz O, Hillen W, Bergwerff AA, Petz M. A new strategy for the analysis of tetracycline residues in foodstuffs by a surface plasmon resonance biosensor. Eur Food Res Technol. 2007;224(3):285-92.

33. Wolter A, Niessner R, Seidel M. Preparation and characterization of functional poly(ethylene glycol) surfaces for the use of antibody microarrays. Anal Chem. 2007;79(12):4529-37.

34. Seidel M, Niessner R. Chemiluminescence microarrays in analytical chemistry: a critical review. Anal Bioanal Chem. 2014;406(23): 5589-612.

35. Seidel M, Niessner R. Automated analytical microarrays: a critical review. Anal Bioanal Chem. 2008;391(5):1521-44.

36. Baron U, Gossen M, Bujard H. Tetracycline-controlled transcription in eukaryotes: novel transactivators with graded transactivation potential. Nucleic Acids Res. 1997;25(14):2723-9.

37. Kloth K, Niessner R, Seidel M. Development of an open standalone platform for regenerable automated microarrays. Biosens Bioelectron. 2009;24(7):2106-12.

38. Lengger S, Otto J, Elsässer D, Schneider O, Tiehm A, Fleischer J, et al. Oligonucleotide microarray chip for the quantification of MS2, $\Phi X 174$, and adenoviruses on the multiplex analysis platform MCR 3. Analytical and Bioanal Chem. 2014;406(14):3323-34.

39. Dizdaroglu M, Jaruga P, Birincioglu M, Rodriguez H. Free radicalinduced damage to DNA: mechanisms and measurement1, 2 1This article is part of a series of reviews on "Oxidative DNA Damage and Repair." The full list of papers may be found on the homepage of the journal. 2Guest Editor: Miral Dizdaroglu. Free Radic Biol Med. 2002;32(11):1102-15.

40. Ward JF, Evans JW, Limoli CL, Calabro-Jones PM. Radiation and hydrogen peroxide induced free radical damage to DNA. Br J Cancer Suppl. 1987;8:105-12.

41. Wutz K, Niessner R, Seidel M. Simultaneous determination of four different antibiotic residues in honey by chemiluminescence multianalyte chip immunoassays. Microchim Acta. 2011;173(1-2):1-9.

42. Petrie B, Proctor K, Youdan J, Barden R, Kasprzyk-Hordern B. Critical evaluation of monitoring strategy for the multi-residue determination of 90 chiral and achiral micropollutants in effluent wastewater. Sci Total Environ. 2017;579:569-78.

43. Literathy P, Laszlo F. Harmonisation of micropollutant monitoring in large international river: Danube. Water Sci Technol. 1995;32(5): 125-37.

44. Batt AL, Bruce IB, Aga DS. Evaluating the vulnerability of surface waters to antibiotic contamination from varying wastewater treatment plant discharges. Environ Pollut. 2006;142(2):295-302.

45. Jentsch A, Beierkuhnlein C. Research frontiers in climate change: effects of extreme meteorological events on ecosystems. Compt Rendus Geosci. 2008;340(9):621-8.

46. Villarini G, Smith JA, Vecchi GA. Changing frequency of heavy rainfall over the Central United States. J Clim. 2013;26(1):351-7.

47. Ghirardini A, Verlicchi P. A review of selected microcontaminants and microorganisms in land runoff and tile drainage in treated sludge-amended soils. Sci Total Environ. 2019;655:939-57.

Publisher's note Springer Nature remains neutral with regard to jurisdictional claims in published maps and institutional affiliations. 